\title{
A review on the health benefits of Monechma ciliatum (Black mahlab):
} A potential functional food

\begin{abstract}
Abdalbasit Adam Mariod ${ }^{1,2^{*}}$, Eshraga Mustafa A. Mustafa ${ }^{3}$, Marwa Bushra Yahia ${ }^{4}$
${ }^{1}$ College of Sciences and Arts-Alkamil, University of Jeddah, Alkamil, Saudi Arabia; 'Indigenous Knowledge Center, Ghibaish College of Science and Technology, Ghibaish, Sudan; ${ }^{3}$ Department of Food Science \& Technology, College of Agricultural Studies, Sudan University of Science \& Technology, Khartoum North, Sudan; ${ }^{4}$ University of Sinnar Faculty of Agriculture, Department of Biotechnology, Sinnar, Sudan
\end{abstract}

*Corresponding Author: Abdalbasit Adam Mariod, PhD, College of Sciences and Arts-Alkamil, University of Jeddah, Alkamil, Saudi Arabia

Submission Date: December 21 $1^{\text {st }}, 2021$; Acceptance Date: January 28 ${ }^{\text {th }}, 2022$; Publication Date: February $9^{\text {th }}, 2022$

Please cite this article as: Mariod A.A., Mustafa E.M.A., Yahia M.B. A review on the health benefits of Monechma ciliatum (Black mahlab): A potential functional food. Functional Foods in Health and Disease 2022; 12(2): 70-80. DOI: https://www.doi.org/10.31989/ffhd.v12i2.879

\begin{abstract}
Background: Monechma ciliatum (MC) (Acanthaceae family) is a herb that grows in tropical and subtropical regions. It grows with small, brownish-black seeds. This is why the Sudanese people call it the "black mahlab". This plant is primarily used in traditional meals, as well as the production of medical treatments and perfumes. Additionally, the seeds of the Monechma ciliatum plant are rich in fats, proteins, minerals, and other essential nutrients. It also functions as an effective laxative. As a result, this plant is commonly found as a supplement in cereal to enrich nutritional value. This review explores the nutritive value, antioxidants, antimicrobial, medicinal, cosmeceutical, and oxytocic properties of Monechma ciliatum seeds, leaves, and stem. To prepare this review, we researched published scientific literature by using the following keywords: "Monechma", "Antioxidants", "Antimicrobial”, nutritional”, "Monechma ciliatum", "Monechma phenolics". Our search was carried out in PubMed and Google Scholar databases and included original research from the past 25 years in English only. A total number of 50 original papers, which mentioned the phytochemistry, nutritional, biological, and medicinal properties of Monechma ciliatum were selected and considered for this review.
\end{abstract}

Keywords: Monechma ciliatum, black mahlab, nutritional, antioxidants, Antimicrobial, oxytocic 


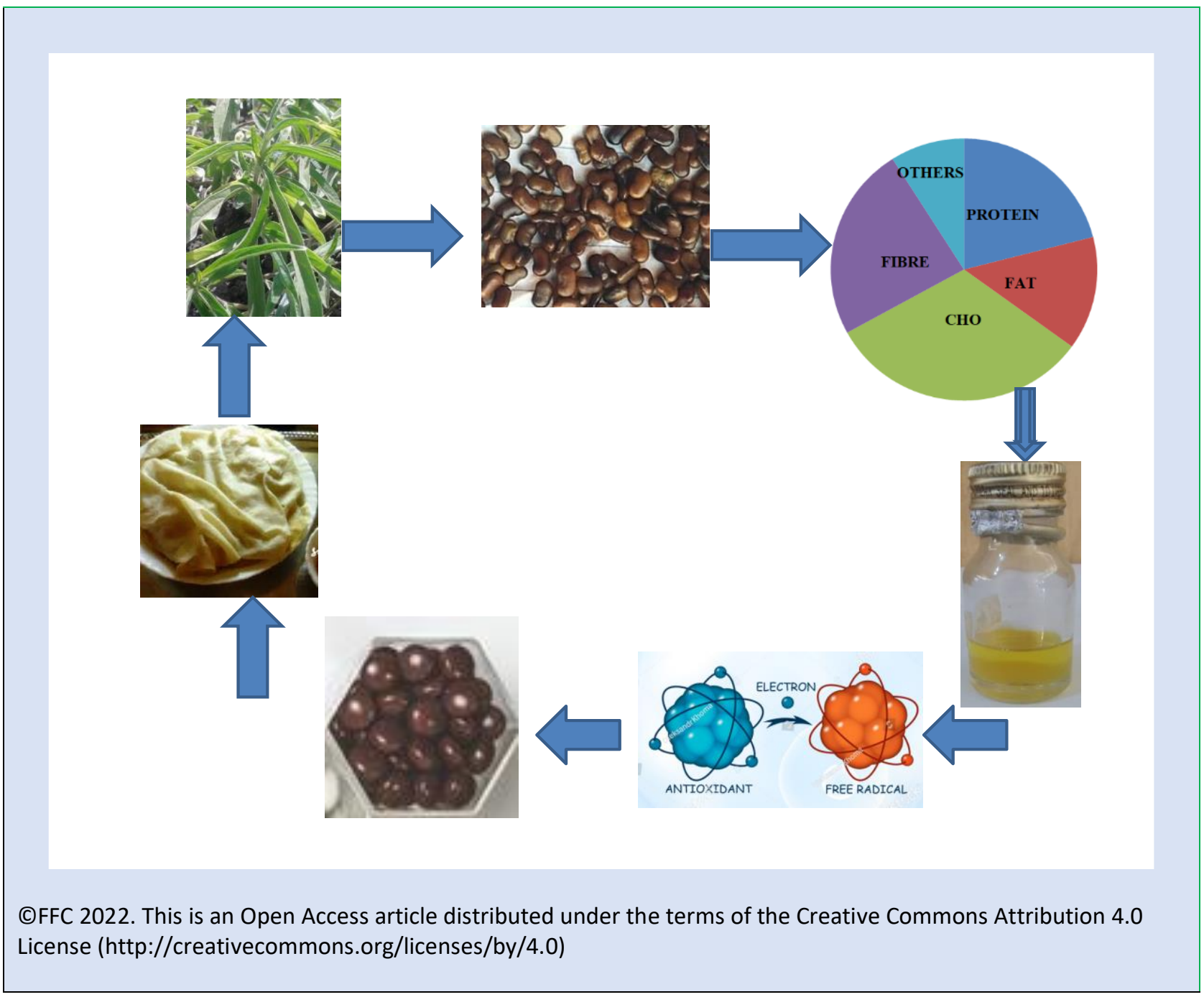

\section{INTRODUCTION}

Generally, plants are considered as good sources of nutrients and supplements for food, as they are important sources of many nutritive component essential for humans and animals feed [1]. Plant-based diets traditionally contain seeds as a key component, and seeds have been shown to have a variety of benefits for health. High-energy foods' replacement with seeds high in protein provides a beneficial effect on the prevention and treatment of obesity, diabetes, and the metabolic syndrome. According to an estimate, $70-80 \%$ of rising world depends on conventional plants to obtain remedies as pharmaceuticals [2]. The Acanthaceae family is a tropical and subtropical native dicotyledonous flowering plants. This family includes about 346 genera and around 4300 species distributed in temperate regions. These plants are mostly found in Indonesia, Malaysia, Africa, Brazil, and Central America. Some spices have colorful flower petals, so they are used as a source of natural dyes [3]. Most spices have high therapeutic applications due to their alkaloid contents [4]. Most species of Acanthaceae family harness valuable components, especially with their leaves and seeds. Studies on many species showed they are used in the treatment of bronchial diseases, relieve bites of poisonous insects, treating reptiles snake bites with and relieve dry cough, diarrhea, flu, and ulcers [5].

The genus Monechma Hochst., is an African genus containing about 60 species. Most of these species are found in tropical and sub-tropical regions, specifically in Southern Africa. Generally, the Monechma species are described as well-adapted plants, as they can to survive in hard environments. As reported by Darbyshire and Goyder [6], twelve species are recorded in Angola, with two of them recently added to Monechma. The same authors reported that there are 
morphological proofs that differentiate the two groups of Monechma in terms of shape, flowers, and fruits.

Monechma ciliatum (Black mahlab) is a species of Monechma genus to the family Acanthaceae. The plant contains unique biochemicals and phytochemical properties that make it traditionally useful for many African populations, especially in rural areas. Monechma ciliatum is an herb, with long leaves, smooth flowers, and seeds with thick hairs at the hilum [7]. Grazing animals can feed on Monechma ciliatum since it can reach $100 \mathrm{~cm}$ in height. Native to Africa and India, this plant has the potential to grow up to one meter high.

This plant is abundant throughout West and East Africa and is widely spread in Sudan [8]. The plant is a small herb that grows a few inches above the ground. Its leaves are simple, measuring about 4-7 x 1-2 cm [9]. In Sudan Monechma ciliatum (known locally as Black mahlab) is found to grow widely in Kassala State, Southern Blue Nile State, Kordofan State, Upper Nile State, Bahr Elghazal State and Bahr Eljebel. The plant is located in the west of Sudan (Jebel Marra) and southwest of Sudan in the Nuba Mountains. In Sudan, the best sowing date was reported to be in the autumn season. Plant spacing positively affects vegetative growth and yield. The wide distance between plants gave higher vegetative and reproduction growth. Successive harvesting was done before fruits reached shattering stage [7]. The seed oil composition revealed that timnodonic, oleic, and linoleic were the basic fatty acids, while the major hydrocarbon and sterol were found to be heneicosane and $\beta$-sitosterol [10].

In Sudan, the plant is well known and traditionally used in treatment and cosmetic, it has small, brownish black seeds, which is why the Sudanese people call it the black mahlab [11]. The species is well known and traditionally used in Kenya, where leaves are grazed by sheep and goats. Additionally, it is harvested at the end of rainy seasons and stored as hay to be used during the dry season [12]. Monechma ciliatum leaves were methanol extracted and administered orally to albino rats. The daily oral administration of $100 \mathrm{mg} / \mathrm{kg}$ extract did not cause lethal effects, and the study showed that the extract was not toxic to the rats. There was no evidence of toxicity [13]. This review is exploring the nutritional and antioxidant, antimicrobial, medicinal properties of Monechma ciliatum.

Monechma ciliatum plantation and reproduction: M.ciliatum can be grown in any tropical and subtropical region of the world with a temperature around 2535으. Mohammed, and Elballa [7], studied the effect of different sowing seasons and row spacing on seed production to determine the optimum sowing date and appropriate plant spacing. They reported that autumn is a better sowing season, and wider plant spacing gave higher values for both vegetative and reproductive growth. Also early sowing date found to be an important factor of seeds oil content (which was also found to be higher in Autumn compared with Winter and Summer seasons). Plant height, number of branches per plant, number of leaves per plant, weight of fresh plants, and weight of dry plants all differed significantly across sowing days [7]. It grows in Kordofan, Darfour and Blue Nile (states of Sudan), where the dried seeds are used to prepare traditional scent, and to treat diarrhea and vomiting [14].

Chemical composition and nutritional value of $\mathbf{M}$. ciliatum: The cost of protein from plants is cheaper than protein from animals in developing countries. Protein content of the M.ciliatum seed as reported by Mariod [11] is $21 \%$ with $783.3 \mathrm{mg} / \mathrm{g} \mathrm{N}$, as an essential amino acids. The M.cilliatum seeds content of fat is $13.15 \%$, with palmitic $4.5 \%$, stearic $16.0 \%$, oleic $47.3 \%$, and linoleic $31.4 \%$, and has a good amount of tocopherols with $45.2 \mathrm{mg} / 100 \mathrm{~g}$. It also contains minerals, and the total phenolic compounds of M.ciliatumm seeds was found to be $17.1 \mathrm{mg} \mathrm{GAE} / \mathrm{g}$ [11]. Hassan et al. [15] examined Monechma ciliatum leaves and concluded they contain 14\% ash, 5.34\% crude protein, $4.14 \%$ crude lipid, $3 \%$ crude fiber, 
available carbohydrates, $73.50 \%$, energy value 352.63(kJ/100 g DW), and a considerable amount of K, $\mathrm{Na}, \mathrm{Ca}, \mathrm{Mg}, \mathrm{Cu}, \mathrm{Fe}, \mathrm{Mn}$, and $\mathrm{Cr}$ as essential minerals. Leaves also contain low levels of anti-nutritional content such as oxalate, phytate, nitrite, cyanide, and tannins (which were below established toxic levels).

M.ciliatum seeds are rich in protein, fat, minerals, and other essential nutrients. Additionally, it has many benefits in traditional treatments [11]. Leaves are also found to be a good source of nutritive compounds and minerals [15]. Mariod, et al. [16] reported that, the predominant phenolic compounds Monechma ciliatum leave (MCL) extracts were $p$-coumaric acid, vanillin, and ferulic acid. They also found that MCL is a potent antioxidant for the stabilization of corn oil. Osman et al. [17]. carried out a phytochemical screening of Monechma ciliatum stem using petroleum ether, methanol, and aqueous extracts. These authors revealed the presence of fatty acids, volatile oils, sterols and triterpenes, basic alkaloids, carotenoids, coumarins, flavone aglycone, emodols, tannins, polyuronides, alkaloid salts, reducing compounds and saponins within the stem.

Aseel [18] investigated seeds of Monechma ciliatum (black mahlab) and Prunus mahleb (white mahlab) collected from Sudan. The materials were then analyzed using diverse chemical tests, and the oil was analyzed using various physicochemical tests according to standard procedures. The findings were then compared. This author reported higher oil content (30.9\%) in white mahlab seed than $13.2 \%$, in black seeds. The two seeds showed palmitic oleic, and linoleic acid as the predominant fatty acids but with different percentages (as black mahlab showed high amount of oleic while white mahlab showed high percentage of linoleic acid). Concerning the content of protein, the author reported white mahlab seed as higher in protein content than black mahlab seed. Many studies have been conducted to validate the traditional uses of the different parts of the plants. As M.ciliatum seeds are previously known as a rich source of protein, fat, minerals and other essential nutrients, Mariod, et al. [19] conducted a study to evaluate the impact of $M$. ciliatum. The focus of this study was on these seeds as a plant-based supplement on sorghum kisra (Sudanese bread made of sorghum flour)as a stable diet for most of Sudanese population. This is in addition to the improvement on its nutritional value, The researchers investigated the effect of composite sorghum flour with untreated, boiled, roasted, and germinated Monechma ciliatum. Their results showed that both the supplementation of sorghum kisra with untreated and treated Monechma ciliatum had significantly and generally improved its nutritional value, specifically with increased fat, fiber, mineral, unsaturated fatty acids, protein, and amino acids content. Additionally, it was found that the addition of 10\% Monechma ciliatum flour to sorghum flour made the organoleptic properties of the product acceptable. They concluded that Monechma ciliatum seed flour could be effective in food fortification.

\section{Effect of processing on $M$. ciliatum seed composition:}

Food processing is the processing and conversion of plant or animal raw materials into products for human or animal consumption. The benefits of food processing include improvement, preservation, and protection from pathogenic microbes and toxic substances. Conversely, some plants lose their nutritive properties through processing as compared to the nutritive contents of the raw. M. ciliatum seeds subjected to three common processing methods by Mariod, et al. [19] these methods included boiling, roasting, and germination. Rresults showed significant positive effects on their nutritive contents. Most of the nutritional values of Monechma ciliatum (MC) were increased by processing. Specifically, all processing techniques increased the protein content, while boiling and roasting increased the fat content. Similarly, boiling and germination techniques increased the fiber content. Saturated fatty acids were increased by roasting and germination processes. Tocopherols were 
increased only in the germinated sample. Amino acids composition was increased with the three processing techniques.

M.ciliatum as food supplement: Much work has gone into increasing the quantity and quality of grain nutrients. These studies used different methods to improve many nutritional and health benefits associated with cereal-based foods. As M.ciliatum seeds previously known as a rich source of protein, fat, minerals and other essential nutrients, Mariod et al. [19] conducted a study to evaluate the impact of $M$. ciliatum as a plant -based supplement on sorghum kisra (Sudanese bread made of sorghum flour as stable diet for most of Sudanese population) and the improvement on its nutritional value, and investigated the effect of composite sorghum flour with untreated, boiled, roasted, and germinated Monechma ciliatum, their results showed that, the supplementation of sorghum kisra with untreated and treated Monechma ciliatum significantly and generally improved its nutritional value, specifically increased fat, fibre, mineral, unsaturated fatty acids, protein and amino acids. This author concluded that sorghum kisra, supplemented with $10 \%$ Monechma ciliatum seed flour, was found to be acceptable with respect to all sensory attributes, and it could be effective in food fortification.

M.ciliatum as animal feed: Hassan et al. [15] concluded that high values of ash content of M.ciliatum leaves may indicate that they contain some nutritionally essential minerals that could develop growth of livestock. Mahlab leaves are used after drying and added to animal feed to compensate for the lack of mineral elements. Ogunsan [12] studied the impact of M.cilliatum on sheep and rabbit feed, where different ratios of M.cilliatum were added to the animals' daily meals. The results showed that, increasing the level of supplementation of M.cillatum beyond $20 \%$ decreased the feed intake and increased live weight of the sheep. They also found that the effect of including M.cilliatum in the diet of rabbits when increasing the level of supplementation of $\mathrm{MC}$ beyond $10 \%$ generally has the same nutritional effects on sheep without harmful effects.

Antioxidant activity of M.cilliatum: The practice of using herbs as food supplement and medicine has been accepted throughout the world. Studies concluded that consuming a variety of antioxidant compounds from natural sources can help in treating serious health disorders [11]. Various chemicals, referred to as antioxidants, incorporate properties that are extremely useful to human beings. This is because they are inclusive of decreasing loose radicals and/or reducing lipid peroxidation, which result in diverse illnesses and ageing results [20]. When consuming natural foods that contain a group of phenols, it reduces health disorders [21]. In addition to increasing nutritional quality and extending food shelf life, natural antioxidants reduce rancidity on foods and prevent toxic oxidation products from forming [22].

M.ciliatum has been used traditionally for treating many kinds of diseases. Studies conducted to support and prove this usage reported that M.cilliatum leave extract has powerful antioxidant effect due to the high content of total phenolic. Their results revealed that, M.cilliatum leaves extract increased the antioxidant activity of corn oil as the extract concentration was increased [23]. Hassan et al. [15] indicated that $M$. ciliatum contains significant amounts of flavonoids, phenols, alkaloids, and other metabolites. Their study also showed that the plant extracts have a promising scavenging activity in comparison to standard ascorbic acid, therefore, their study concluded that M. ciliatum leaves are a potential source of natural antioxidants. These results give a strong impetus to other researchers on in-depth studies in vitro and in vivo to find out the role of the bioactive ingredients responsible for these activities (in addition to 
conducting studies at the molecular level) [15]. Antioxidant activity of M.cilliatum seed extract revealed that, the seeds phenolic rich fractions (PRFs) had the highest antioxidant activity, therefore, it reduced the oxidation of $\beta$-carotene by hydro peroxides from the extracts [11]. Monechma ciliatum is used in many African countries, including Sudan, in the treatment of many diseases such as body pain, liver disease, cold, diarrhea, and in the treatment of infertility in women. Hassan et al. [15] carried out an invitro antioxidant activity of $M$. ciliatum methanol, ethyl acetate and $n$-hexane leaves extract respectively. The researchers stated that $M$. ciliatum has a good radicalremoving activity, which facilitates a process that can be greatly compared to standard ascorbic acid. Therefore, the possibility that the leaves are a source of natural antioxidants is very high. It is known that active plant compounds are secondary metabolites that allow plants to overcome pathological infections caused by microbes or chemical transformations of plant cells. Thus, humans can extract, purify, identify, and use them in medical treatmenta. The results of Hassan et al. [15] proved that methanol is the most appropriate solvent to extract these bioactive compounds.

Anti-microbial activity of M.cilliatum: Many studies have shown that traditional folk medicine uses many medicinal plants to treat skin diseases that caused by bacteria and fungi. Many Sudanese use black mahlab seed powder and its aqueous extract to treat skin problems and infections of the mucous membranes and gingivitis [11]. Traditional uses of $M$. ciliatum against microbial diseases encourage researchers to conduct experiments to prove and support these traditional beliefs by identifying the effective components and the suitable amounts and methods that should be used to obtain the benefits. Microbial activity of Monechma ciliatum showed a significant antibacterial activity against Bacillus subtilis, Staphylococcus aereus, Escherichia coli and
Pseudomonas aeraginosa compared with well-known antibiotics and antifungal activity against Cladosporium cucumerinum and Candida albicans. Studies on the seed's extracts, seedcakes, and leaves showed they have great contents of nutrients as antioxidant, antimicrobial, and medicinal components [23]. Pharmacologically speaking, the crude plant extracts are more active than the active isolated extracts due to the synergistic effects of the components of those extracts [24].

In a phytochemical screening conducted by Oshi and Abdelkarim [23], their result supported these traditional uses in the therapy of respiratory tract infections caused by a wide range of microbes and fungi. They found that this is due to the seed content of flavonoids, tannins, tritepens, and Quinone's. These anti-microbes affected Staphylococcus aurous, which was sensitive to both water and ethanol extracts. Klebsiella pneumonia and Pseudomonas aeruginosa was found to be insensitive to ethanol extract while fungi were found to be insensitive to all extracts used. The results indicated that raw Monechma ciliatum seed extract was tested instead of the isolated compound due to the potential for synergistic effect. Osman [17] studied the antimicrobial activity $M$. ciliatum stem using three extracts and reported that this is due to its content of many active components (fatty acids, alkaloids, essential oils, triterpenes, phytosterols and carotenoids, phenolic compounds, tannins, alkaloid salts, reducing compounds and saponins) and suggested that the most active components were found in methanolic and petroleum ether extracts [17]. Also, Abdel Karim et al. [25] examined the antimicrobial activity of the seeds oil of $M$. ciliatum and reported that it has a significant effect on Aspergillus niger and Candida albicans fungi and Staphylococcus aureus bacteria. The oil found to be partially active against Escherichia coli and Pseudomonas aeruginosa. However, it was found inactive against Bacillus subtilis. Assessment of antibacterial efficacy of different Monechma ciliatum leave extracts revealed that 
Staphylococcus aureus, beta Streptococcus haemolyticus group A, Pseudomonas aeruginosa and Escherichia coli exhibited remarkable sensitivity to petroleum ether extract (Proteus mimrabilis and Klebsiella pneurnoniae to chloroform extract, and Salmonella typhi to methanol extract). Petroleum ether extract exhibited the highest antifungal efficiency against all tested fungal species. They attributed these different effects to the presence of phenols, sterols in petroleum ether and chloroform extracts, whereas tannins, flavonoids, coumarins, saponins and triterpenoids in methanol extract. In the same manner, Abuelgasim et al. [26] studied the antimicrobial activities of extracts of Monechma cilatum stem and leaves and reported that, the concentration of the active antimicrobial constituents is different in leaves and stem of Monechma cilatum. Therefore, methanolic leave extract was more effective with standard bacteria (Gram positive and Gram negative) while fungi was less sensitive to same extracts. Abdalla [27] conducted a research on Monechma ciliatum to know its antimicrobial activity and its pharmacological properties. He found that the chloroform extracts of the leaves had low antibacterial activity against $S$. aureus, Bacillus subtilis, Candida albicans, Escherichia coli, Proteus common and Pseudomonas aeruginosa. The microbial activity of the methanolic extract of Mahlab leaves was moderate against Proteus common and Escherichia coli, and low against Bacillus subtilis, Pseudomonas aeruginosa and Staphylococcus aureus. This activity was absent for Candida albicans and Aspergillus niger [27].

Uterotonic property of M.ciliatum: For a long time, plants that have the ability to contract the uterus (and are known as uterotonics) have been used to induce labor. Uterotonics are also used in abortions [28]. Uguru [29] tested the extracts of Monechma ciliatum leaves using different solvents for oxytocic properties of parturition for experimental mice in uterine preparations. It was found that the methanol extract was more effective on the uterus of non-pregnant mice and guinea pig, while the uterus of pregnant rats was not affected by the extract. The study also showed that there was no abortive effect of hot methanol extract when administered orally to rats in the second week of pregnancy compared to oxytocin. However, on day 23, it was discovered that the fetus died in the womb. They also found that the extract had estrogenic activity resulting from the circumstances. In an attempt to explain the mechanism of action of the hot methanolic extract of Monechma ciliatum leaves, Uguru et al. [8] compared the oxytocin activity of this extract with other uterine stimulants (such as ergometrine, oxytocin, 5-hydroxytryptamine, acetylcholine, and prostaglandins) in the presence of some antibiotics.

Uguru [30] purified the hot methanol extract of Monechma ciliatum to isolate the oxytocic principle. The polarity of the oxytocic is significant as a positive reaction with ninhydrin-spray suggests that it is an amino acid. With the addition of a bioassay and repeated column chromatography on silica gel followed by sephadex LH-20 on the rat uterus, the researchers partially identified the oxytocic principal (P3). This was suggested by previous studies as small peptide constructed of tyrosine, leucine and a third constituent to be most likely serine. To validate the traditional beliefs and uses of M.ciliatum to reduce pain and ease parturition, antinociceptive effect of Monechma ciliatrum was studied by Meraiyebu [31]. using a Von Frey's aesthesiometer. Their results showed that giving the extract both orally and intrathecally has an anti-painful effect. Additionally, it has a greater effect orally in the first quarter of an hour during intrathecal administration. Electroencephalogram (EEG) readings were also taken for all the groups. There was a decrease in amplitude and an increase in frequency for high dose (1000 $\mathrm{mg} / \mathrm{ml}$ ). Additionally, mid brain electrodes produced a change from theta (3.5 - 7 waves per second) to alpha waves (7.5 - 13 waves per second) (similar to that found in relaxed individuals). However, amplitude beta wave 
distributions were changed and reduced, revealing similar properties for sedative hypnotic drugs.

Medicinal uses of M.ciliatum: Plants as disease treatments have been used alongside modern drugs worldwide. Every individual has used different plants as a medicinal treatment in some form. Some researchers have proven that Monechma ciliatum is used as a medicine for female infertility, liver disease, and diarrhea [32]. Residents of the Sudanese Nuba Mountains use black mahlab seeds to treat asthma and colds. They also use it as an anthelmintic and antidysentery [13]. As in Botswana, black mahlab is used as a pain reliever and treatment for various kidney and liver diseases [32]. Malaria is one of the most common health problems all over the world, so Shayoub [33] studied and evaluated the extract of $M$. ciliatum and its efficacy as an antimalarial Plasmodium falciparum. The extracts were studied with several different solvents. These solvents had variable concentrations of 125, 250 and $500 \mu \mathrm{g} / \mathrm{ml}$. The results showed that extracts of $M$. ciliatum have strong antimalarial activities.

Another study on medicinal use of $M$. ciliatum was carried out by Mariod, et al. [34] on the effects of M. cilliattm methanolic extract (MCME) on low density lipoprotein receptor (LDLR). They concluded that MCME concentration played a major role, and different doses showed significant differences in regulation of both LDLR and 3-Hydroxy-3-Methylglutaryl-CoA Reductase (HMGCR) genes. The results showed that the methanolic extract of black mahlab regulates LDLR and HMGCR genes that significantly affect cholesterol metabolism in HepG2 cells. According to the African traditional medicinal uses, Monechma ciliatum seed powder soaked in water and drunk or burnt can act as an inhalation for cold and allergic condition treatment. To validate these traditional beliefs, Oshi and Abdelkareem [23] formulated and studied a conventional dosage form (tablets) from Monechma ciliatum seed's ethanolic extract using the wet granulation method. Two formulations were prepared, the first using starch as a binder and disintegrant, and the second using polyvinylpyrrolidene and cross-linked cellulose with carmellose as a binder and disintegrant.

They conducted a study using oleic acid, coumarin, 1,2-dioleoylglycerol, and 1,3dioleoylglycerol isolated from water extract of $M$. ciliatum seeds. This was to observe these components activity of $P$. gingivalis. Their results validated the application of using $M$. ciliatum as an effective therapeutic agent to prevent periodontal diseases [35].

\section{Anticancer activity}

Essential oils contain many effective compounds that are useful in treating cancer [36]. Cereals, vegetables, and fruits contain phenols and flavonoids (which are very important and effective plant compounds). These secondary metabolites are natural antioxidants that protect the body from cardiovascular disease, aging, and cancer (based on their multiple biological effects) [37].

Cosmetical uses of M.cilliatum seeds: Based on what is found in literature of traditional medicine, medicinal herbs have been used throughout the ages in cosmetic operations. Herbal extracts have been utilized for different skin and hair diseases. Market research reports increasing demand in the herbal and cosmetic industry, therefore playing a major role in fueling this worldwide demand. The recent interest of consumers in herbal cosmetics has been attribute to declining faith in modern chemical cosmetics.

Sudanese women use the seeds of black mahlab in the preparation of cosmetics and perfumes that are used in marriage and childbirth rituals [11]. It is one of the useful odor plants in nomadic area of Western Sudan. Oshi, et al. [16] conducted a study to validate the claim of inhalation of Monechma ciliatum seeds powder from traditional African natives and Sudanese people in Nubia Mountains regions. The researchers 
concluded that the traditional uses of M.cilliatum seeds for cosmetics purposes referred to antioxidant activity of flavonoids and tannins. These components are considered as effective substitutes to limiting the damage caused by free radicals of skin. The triterpenes and sterols are aromatic constitutes of medicinal plants. The high antibacterial activity against Staphylococcus aureus, Bacillus subtilis, Klebsiella pncumoniae, Escherichia coli, Candida albicans and Aspergillus niger of black mahlab seeds provides scientific evidence for the traditional uses of black mahlab seeds as a cosmetical treatment for skin and mucous membrane disorders [16].

\section{CONCLUSION}

It is clear that the seeds of M.ciliatum possess many benefits. For example, they contain valuable sources of human nutrients. Addtitionally, the leaves are good for animal feed. Most parts of the plant also have great antioxidant, anti-microbial, and cosmetic properties. Further work on these properties is needed to corroborate the primary mechanisms as antioxidants and antimicrobial agents. The plant could become a valuable source of income if commercially exploited by food and medical researchers and industries. Table 1 summarizes some of the findings in this review article.

Table 1. Some investigated biological activities, chemical and phytochemical composition of Monechma ciliatuim

\begin{tabular}{|c|c|c|}
\hline Biological activities & Plant part and extracting solvent & Source \\
\hline Antioxidant activity & Anti-microbial activity & 23,15 \\
\hline Antioxidant activity & Seed & 11,15 \\
\hline Anti-microbial activity & Seed & $11,23,24$ \\
\hline Anti-microbial activity & Stem & 17,26 \\
\hline Anti-microbial activity & Seed's oil & 25 \\
\hline Anti-microbial activity & Leaves & 26,27 \\
\hline Uterotonic property & Leaves & $8,28,29,30$ \\
\hline Anthelmintic and anti-dysentery & The whole plant & 13,32 \\
\hline Antimalarial activity & The whole plant & 33 \\
\hline Regulation of genes & Seedcake & 34 \\
\hline Anticancer activity & Essential oil & 36,37 \\
\hline Cosmetical uses & Seed & 11,16 \\
\hline \multicolumn{3}{|c|}{ Chemical and phytochemical composition } \\
\hline Plant part & Composition & Source \\
\hline Seed & Protein, carbohydrates, lipid, fiber, minerals, amino acids, & $11,18,19$ \\
\hline Leaves & $\begin{array}{l}\text { Ash, crude protein, crude lipid, crude fiber, carbohydrate, } \\
\text { minerals ( } \mathrm{K}, \mathrm{Na}, \mathrm{Ca}, \mathrm{Mg}, \mathrm{Cu}, \mathrm{Fe}, \mathrm{Mn} \text {, and } \mathrm{Cr} \text { ), phenolic } \\
\text { compounds ( } p \text {-coumaric acid, vanillin and ferulic) }\end{array}$ & $12,15,16,23$ \\
\hline Stem & $\begin{array}{l}\text { Fatty acids, volatile oils, sterols and triterpenes, basic } \\
\text { alkaloids, carotenoids, coumarins, flavone aglycone, emodols, } \\
\text { tannins, polyuronides, alkaloid salts, reducing compounds and } \\
\text { saponins }\end{array}$ & 17 \\
\hline Seed oil & Fatty acids, palmitic, stearic, oleic, linoleic, tocopherols & 11,25 \\
\hline
\end{tabular}


List of Abbreviations EEG: Electroencephalogram, HMGCR: 3-Hydroxy-3-Methylglutaryl-CoA Reductase, LDLR: Low density lipoprotein receptor, MC: Monechma ciliatum, MCL: Monechma ciliatum leave, MCME: M. cilliattm methanolic extract, PRFs: Phenolic rich fractions

Competing Interests: No financial interests or personal relationships between the authors influence the research.

Authors' Contributions: Mariod had the original concept for the presented idea, and Mustafa and Yahia wrote the manuscript draft with support from Mariod. All of the authors discussed the reviewed results and contributed to the final manuscript. All authors also contributed to the final version of the review manuscript.

\section{REFERENCES}

1. Valvi, S. and Rathod V: Mineral composition of some wild edible fruits from Kolhapur district. Inter. J. appl. bio Pharm. Technol. 2011, 2(1): 392-396.

2. Awan, A. J., Ahmed, C. B., Uzair, M., Aslam, M. S., Farooq, U., Ishfaq, K: Family Acanthaceae and genus Aphelandra: ethnopharmacological and phytochemical review. Int. J. Pharm. Pharm. Sci. 2014, 10(6):44-55.

3. Ali, M.A.F: Phytochemical and Biological Studies of Certain Plants Belonging to Family Acanthaceae. Ph.D. Thesis, Assiut University, Faculty of Pharmacy,. 2013, https://doi.org/10.13140/RG.2.2.20951.01440

4. Sharma, A., and Kumar, A: Acathaceae taxonomy and uses in traditional medicinal system. World J. Pharm. Res. 2016, 5(7): 403-412. https://doi.org/10.20959/wjpr20167-6522

5. Hossain, M.T. and Hoq, M.O: Therapeutic use of Adhatoda vasica. Asian J. Med. Biol. Res. 2016, 2(2): 156-163. https://doi.org/10.3329/ajmbr.v2i2.29005

6. Darbyshire, I. and Goyder, D: Notes on Justicia sect. Monechma (Acanthaceae) in Angola, including two new species. Blumea J. Plant Tax. Plant Geog. 2019, 64: 97-107. https://doi.org/10.3767/blumea.2019.64.02.01

7. Mohammed, T. M. S. and Elballa M. M. A: The Effect of Agricultural Practices on Growth and Yield of Black Mahlab (Monechma ciliatum). Agri. Bio. Sci. J. 2015, 1(2): 31-36

8. Uguru, M.O., Okwuasaba, F.K., Ekwenchi, E.E., Uguru, V. E: Uterotonic properties of the methanol extract of Monechma ciliatum. J. Ethnopharm. 1998. 62(3):203-208. https://doi.org/10.1016/s0378-8741(98)00037-3

9. Oshi, M.A. and A.M. Abdelkarim: Phytochemical screening and evaluation of Monechma ciliatum (black mahlab) seed extracts as antimicrobial agents. Avicenna J Phytomed. 2013;3(2):126-134.

10. Mead, H. M., El-Shafiey, S. N., Sabry, H. M: Chemical constituents and ovicidal effects of mahlab, Prunus mahaleb L. kernels oil on cotton leafworm, Spodoptera littoralis (Boisd.) eggs. J. Plant Prot. Res. 2016, 56, 3:279290. https://doi.org/10.1515/ippr-2016-0044

11. Mariod, A.A., Aseel, K.M., Mustafa, A.A., Abdelwahab, S. I: Characterization of the Seed Oil and Meal from Monechma ciliatum and Prunus mahaleb Seeds. J. Am. Oil Chem. Soc. 2009, 86(8): 749-755. https://doi.org/10.1007/s11746-0091415-2

12. Ogunsan, E. A., Ehizibolo, D.O., Dashe, Y.G., Jatau, J.D., Tambuwal, F.M., Dogo, G.I., Osuji, N.K., Sugun M.Y: Potentials of Monechma ciliatum as a Non-conventional Feedstuff in Sheep Diet in Sokoto, Nigeria. Pak. J. Nut., 2011, 10 (10): 987990. doi.org/10.3923/pjn.2011.987.990

13. Uguru, M.O., and Evan F: Phytochemical and pharmacological studies on Monechma ciliatum. J. Ethnopharm. 2000, 73: 289292. doi.org/10.1016/s0378-8741(00) 00236-1

14. Oshi, M.A.M., Abdelkareem, A.M., Eltohami, M.SH: Phytochemical and antimicrobial activity of Monechma ciliatum (black mahlab) seed extracts. J. Herb. Drugs. 2013, 4, 1: $15-22$.

15. Hassan, L.G., Msheila, H. E., Umar, K. J., Umar A. Umar and Onu, A: Nutritional and Anti-nutritional Analysis of Monechma ciliatum Leaves. Rese. J. Food Sci. Nutr. 2018, 3(3): 23-30. https://doi.org/10.31248/RJFSN2018.040

16. Mariod, A. A., Ibrahim, R. M., Ismail, M., Ismail, N: Antioxidant Activity of the Phenolic Leaf Extracts from Monechma ciliatum in Stabilization of Corn Oil, J. Am. Oil Chem. Soc. 2010, 87(1): 35-43. https://doi.org/10.1007/s11746-009-1474-4

17. Osman, S.B.H: Chemical Composition and Antimicrobial Activity of Monechma ciliatum (Jacq.) Milne-Redhead Stem. Ph.D. Thesis, Al Neelain University, Faculty of Science, Khartoum, Sudan; 2007

18. Aseel, K.M: Investigating two varieties of mahlab seeds: oil, fatty acids, and amino acids, M.Sc. Thesis, Sudan University of Science and Technology, Department of Food Science and Technology, , Khartoum north, Sudan; 2008.

19. Mariod, A., Abdalrahman, E., Shakak, M: Impact of incorporation of Monechma ciliatum seed flour on the chemical composition, nutritional value and sensory evaluation of sorghum Kisra. Egyptian J. Food Sci. 2021, 49, (1):97-106. https://doi.org/10.21608/EJFS.2021.45938.1082 
20. Galati, G., and Brien, P. J: Potential toxicity of flavonoids and other dietary phenolics: Significance for their chemopreventive and anti-cancer properties. Free Radic. Biol. Med. 2004, 37: 287-303.

\section{https://doi.org/10.1016/j.freeradbiomed.2004.04.034}

21. Shahidi, F. and Ambigaipalan, P: Phenolics and polyphenolics in foods, beverages and spices: Antioxidant activity and health effects - A review. J. Fun. Foods. 2015, 18, Part B, 820-897. https://doi.org/10.1016/j.jff.2015.06.018

22. Jadhav, S., Nimbalkar, S. S., Kulkarni, A. D Madhavi, D. L: Lipid oxidation in Food and Biological Systems: IN: Food Antioxidants. Technological: Toxicological and Health Perspectives $1^{\text {st }}$ edition. Edited by D.L. Madhavi, S.S. Deshpande, D.K. Salunkhe. CRC Press; 1996:5-63. https://doi.org/10.1201/9781482273175.

23. Oshi, M. and A. Abdelkareem, 2013b. Design and evaluation of cost effective conventional tablets from Monechma ciliatum seeds extract. Inter. J. Pharm. Sci. Res. 4(2): 634. http://dx.doi.org/10.13040/IJPSR.0975-8232.4(2).634-43

24. Padmanabhan, P. and Jangle, S. 2012. Evaluation of in-vitro anti-inflammatory activity of herbal preparation, a combination of four medicinal plants. Inter. J. Basic App.Med. Sci. 2012. 2(1):109-116.

25. Abdel Karim, M., Faiza, I., Inas, O. 2017. Monechma ciliatum Oil: GC-MS Analysis and Antimicrobial Activity. Inter. J. Sci. Eng. App. Sci. (IJSEAS) -3, 2395-3470.

26. Abulgasim A. I, A.M.I., Hassan. A. 2015. Antimicrobial activities of extracts for some of medicinal plants. Inter. J. Adv App. Sci. 2 (2): 1-5.

27. Abdalla, M.I.A. 2008. Antimicrobial and pharmacological properties of some medicinal plants, M.Sc. Thesis, University of Khartoum, Faculty of Veterinary Medicine, Khartoum, Sudan.

28. Roqaiya, M., Begum, W., Majeedi, S. F., Saiyed, A. 2015. A review on herbs with uterotonic property. J. Phytopharm. $4(3): 190-196$.

29. Uguru, M. O., Okwuasaba, F. K., Ekwenchi, M. M., Uguru V. E. 1995. Oxytocic and oestrogenic effects of Monechma ciliatum methanol extract in vivo and in vitro in rodents. Phytother. Res. 9(1): 26-29. https://doi.org/10.1002/ptr.2650090107

30. Uguru, M., Ekwenchi, M., Evans, F. 1999. Bioassay-directed isolation of oxytocic principles from the methanol extract of Monechma ciliatum. Phytother Res.. 1999 Dec;13(8):696-9. https://doi.org/10.1002/(SICI)10991573(199912)13:8<696::AID-PTR549>3.0.CO;2-7

31. Meraiyebu, A.B. and Adelaiye, A.B. 2010. The antinociceptive effects of Monechma ciliatum and changes in EEG waves following oral and intrathecal administration in rats. Proc. SPIE
7552, Mechanisms for Low-Light Therapy V, 75520Q (4 March 2010); https://doi.org/10.1117/12.846101.

32. Inga, H., and Stangard, F. Traditional Medicine in Botswana. Traditional Medicinal Plants. Ipelegeng Publisher, 1989. Sweden

33. Shayoub S.A.M.El., Elhassan, A. M., Kabbashi A. S., Ahmed, M. El. A., Shayoub, M. El. A. 2016. Anti-malarial activity of Monechma ciliatum (black mahlab). World J. Pharm. Res. 5, (5):200-212. https://doi.org/10.20959/wipr20165-6148

34. Mariod, A.A., Ghanya, A.-N., Ismail, M. 2010. Monechma ciliatum methanolic extract regulates low density lipoprotein receptor and 3-hydroxy-3-methylglutaryl coenzyme A reductase genes expression in HepG2 cells. African J. Biotech. 9(36), 5813-5819

35. Eltigani, S.A., Eltayeb, M.M., Ishihara, A., Arima, J. 2019. Isolates from Monechma ciliatum seeds' extract hampered Porphyromonas gingivalis hemagglutinins. J Food Biochem. 2019 Nov;43(11):e13029. https://doi.org/10.1111/jfbc.13029

36. Oliveira, C. M. 2015.Chemical Characterization and in Vitro Antitumor Activity of the Essential Oils from the Leaves and Flowers of Callistemon viminalis. American Journal of Plant Sciences, 6, 2664-2671. https://doi.org/10.4236/ajps.2015.616268

37. Tungmunnithum, D., Thongboonyou A, Pholboon A, Yangsabai A. 2018. Flavonoids and other phenolic compounds from medicinal plants for pharmaceutical and medical aspects: An overview. Med. 5(3): 93 https://doi.org/10.3390/medicines5030093 